\title{
Dodges for Heterosexuality \\ - Young Boys viewing Male Bodies in Pornography
}

Af Niels Ulruk Sørensen

When young boys watch male bodies in pornography, their positions as beterosexual and masculine may be challenged. But young boys bave various strategies to meet these challenges. However, sometimes they are forced to choose between beterosexuality and masculinity. But dismissing beterosexuality does not seem to be an option.

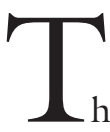

hough pornography consumption among young people in Scandinavia generally has increased, still more young boys than young girls use it, and more young boys than young girls use it on a daily basis (Sørensen \& Kjørholt 2007). As much pornography revolves around female characters, this has caused some public debate about the conceptions of female bodies and sexualities that young boys construe in their use of pornography (Sørensen 2003). Far less has been said about their conceptions of male bodies and sexualities. However, media studies have drawn attention to a remarkable proliferation of objectified male bodies and sexualities in nonpornographic visual mass media products in recent decades (Bordo 2000, Gill et al. 2003, Still 2003). And scholars who have studied masculinity have argued that young boys increasingly identify with these bodies and sexualities and use them as standards of reference for modelling their own bodies and sexualities (Mort 1996, Edwards 1997, 
Johansson 1997, 2005, Sørensen 2005, 2006). This has caused some public debate about the de-masculinisation of young boys, who presumably lose their masculinity concurrently with the objectification of their bodies and sexualities (Sørensen 2005).

This perspective has been less prevalent in the public debate about pornography. Though the notion of de-masculinisation may not be useful for comprehending the relationship between young boys and the objectified male bodies and sexualities in pornography, it can remind us that this relationship exists. It can also remind us that young boys' use of pornography is not only about viewing female bodies and sexualities. There are male bodies and sexualities involved too. And in the same way that images of male bodies and sexualities outside pornography contribute to young boys' construction of bodies and sexualities, male bodies and sexualities in pornography may contribute to this construction too. There has not been much research about this particular issue, though it was taken up in a recent American study in relation to a group of adult heterosexual men (Eck 2003). They distanced themselves unambiguously from nude male images - to relate to them even remotely seemed incompatible with their positions as male heterosexuals. However, young boys in Scandinavia may relate differently to such images. And this may not necessarily be a question of a de-masculinisation. In stead a transformation of a particular historical notion of gender and sexuality could be at stake.

In most of the modern era, men viewing men was not only considered a peripheral but also a touchy subject. The body depicted for aesthetic and sexual pleasure was primarily the female body. Men were not supposed to be looked at - but to look. The gendered distribution of positions was clear: If you were a man you were considered a spectator, if you were a woman you were considered a spectacle (Björk 1999; Still
2003). This distribution of course was entwined with a strong norm of heterosexuality. Only heterosexuality was supposed to bridge men and women, standing on their own masculine and feminine banks - these banks having been defined as dichotomous and thus unbridgeable. Women and men moving to the opposite bank by other means were likely to be excluded from heterosexuality and absorbed by homosexuality or other deviant sexualities. Just as men and women practicing non-heterosexual sexualities were likely to be excluded from their own gender and become de-humanised (Butler 1993, Connell 1995). Though the dichotomical organization of gender and the norm of heterosexuality were compromised and reworked in the everydaylives, it is not until recently that is has become reworked on a larger scale.

As men and women in late-modern Scandinavia to a great extend live their lives on the same arenas and perform the same tasks, they increasingly crisscross between gendered and sexualised positions: feminine positions are no longer exclusively for women, masculine positions no longer exclusively for men, and crossing over no longer is unavoidably associated with homosexuality. However, this does not mean that anything goes: men are still expected to be predominantly masculine, women are still expected to be predominantly feminine, and both are still expected to be heterosexual. But as they continuously crisscross between masculine and feminine, heterosexual and homosexual positions, what defines these positions become more and more unclear. Constructing oneself as a predominantly masculine and heterosexual male or a predominantly and heterosexual female therefore not only requires an ability to integrate and balance already gendered and sexualised positions but also an ability to reinterpret and redefine these positions (e.g. Søndergaard 1996, Johansson 2005, Sørensen 2005,2006).

This article explores one particular point 
of impact in this process: the reconstruction of gendered and sexualised positions which takes place in young Danish boys' use of pornography. The article is based on interviews with 10 boys. ${ }^{1}$ In the article I will explore the ways the young boys construct the relationship between male viewers and male bodies in pornography and how gendered and sexualised positions are reinterpreted and redefined in the process.

\section{SELECTING THE INFORMANTS}

The interviews took place in the autumn of 2005. The boys were 15 and 16 years old, and they were in ninth or tenth grade. One went to a regular public school in Copenhagen, whereas the others went to continuation schools. Eight of these went to two different schools in the Copenhagen area, and one went to a continuation-school in another part of the country. However, all of the boys were mostly brought up in locations situated less than an hour from Copenhagen. They all had middle-class backgrounds, and none of them came from immigrant or ethnical minority families. They did not have any explicit religious or spiritual affiliations either. Half of them had divorced parents, but they all lived with either their mother or father, who was in a new heterosexual relationship.

My first attempts to recruit young boys for interviews in Copenhagen elementary schools fell to the ground. It was quite easy to find young boys who would volunteer as interviewees, when I presented the project in the class-rooms. But they did not give their parents the document of approval and bring it back to me with a signature. However it did seem less problematic for boys in continuation schools to get their parents' signature, even though they only saw them over the weekends. A continuation-school is a one or two year boarding school where young people can take the last classes of elementary school. But it is also a new beginning - and a step away from childhood into an emerging youth. By volunteering to be interviewed about gender and sexuality, the 10 young boys distanced themselves from their childhood identities and seized the youth cultural context of the continuation schools. However it did take some self-confidence and courage of each boy to bring sensitive aspects of their own lives into play in an interview with an adult male researcher that they did not know.

\section{THE NATURAL ORDER OF THINGS}

"In the world of porno women are an exhibit.... Women are such an essential thing in porn. They've got to be the centre of attention.... I guess it's more natural that women exhibit themselves like that.... Porn has always been a man's world, hasn't it? It's a male thing created by men for men.... I don't really think that it's a problem that men aren't exhibits like that. I would consider that weird" (Magnus). ${ }^{2}$

In the quotation above Magnus explains gender-relations in pornography in accordance with the modern notion of the male spectator and the female spectacle: Men view pornography to view women. And women are in pornography to be viewed by men. According to Magnus, there is nothing weird about that. It is the natural order of things or at least it is essential to the pornographic: The male spectator and the female spectacle are presented as constitutive of pornography, which therefore would not be pornography without this particular distribution of gender positions. Only one of the young boys - Jacob - makes a problem of this distribution, calling it "very male chauvinist", as "the women are just there to get fucked, if you feel like it". But the rest of the young boys do not apply such a critical feminist perspective in their descriptions of the distribution of genderpositions in pornography. On the contrary, they tend to agree with Magnus that these positions reflect the state of things, and 
they do not envision how they might be otherwise. This however should be seen in the light of the interview situation: They are being interviewed about their use of pornography in a homo-social context that might have certain heterosexual connotations. And the more they can establish a general understanding of the distributions of gender positions in pornography - and not least the heterosexual relationship bridging these positions - the easier they can present their own use of pornography as heterosexual. And that seems to be important for them.

The young boys use generalising nouns and pronouns when they describe their own use of pornography. It is a sensitive subject, and the generalisations are used to circumvent talking too specifically and concretely about their personal experiences with this subject. But they particularly use them to stage their use as heterosexual and themselves as heterosexuals. The staging is done in several ways. Apart from naturalizing the distribution of gender positions and the heterosexuality inherent in them, they continuously focus on the female bodies during the interviews - and not only when they talk about the qualities of these bodies, but also when they talk about the male users' interest in these bodies. This interest is presented as all encompassing and depersonalised and, thus, also including the young boys themselves. "People like to watch good-looking girls who get it in their heads and their asses", Linus states. "The more of the opposite sex the better", Felix says. "Then you watch four boobs instead of two", Jens notes. And this explanation seems to be sufficient: Four boobs have to be better than two, when an interest in the female bodies is the unifying and inviolable interest of the "people" and "you" who use pornography. By relating the interest in the female characters to these all-encompassing and depersonalised user categories, the boys make it meaningless to articulate users with other interests.
They become more or less impossible as user categories, wherefore they are left as unspoken and silenced deviances, which the young boys do not have to relate to or be associated with. This generalisation of the interest in female bodies shields the young boys from being positioned against or outside the male heterosexual user category, as the generalisation makes such a positioning is made meaningless and impossible.

\section{The Natural Order of Things DisTURBED}

To explore the young boys' relation to male bodies in pornography, I somehow had to get beyond their generalised interest in female bodies, which seemed to silence them on most aspects of such a relation. I did not intend to throw suspicion on their interest in the female bodies. But I needed to create a platform where this interest could be articulated in a less than all-encompassing and de-personalised manner, so the young boys could relate to male bodies without excluding themselves as meaningless and impossible users of pornography. I was quite sure that they related to the male bodies one way or the other. For even though their interests were formulated as "good-looking girls who get it in their heads and their asses", someone must be there giving it to them. And as the boys themselves said that they viewed heterosexual pornography, that 'someone ', in many instances, had to be one or even more male characters with male bodies. To create a platform where they could talk about these bodies, I showed them non-pornographic pictures of young men with bare torsos and asked them to comment on them.

Though the pictures did make the young boys talk, they uttered several prefatory remarks demonstrating their disinterest in what they saw. Confronted with a picture of a young guy in boxer-shorts, the young boys' reactions were unambiguous - and snappy. "Ugh! That's a man in his under- 
wear", Jens blurted out. Hans' reaction was: "I don't really feel like looking at that". Magnus took it more humorously but was not less unaccommodating: "I don't want that picture as the background of my computer-screen". When asked to explain their prefatory dismissals of the young guy in his underwear, their reactions were equally unambiguous - and snappy: "I'm not into men", Jens explained. Anders said: "I can't judge it, because I'm not into men". Hans tried a more obliging approach by saying: "A picture like that would be more interesting for a girl". Although Hans' answer did indicate that women can be spectators and men spectacles - and that gender-positions thus might not be as rigid as stated above - his answer also implied that he is a boy - not a girl and therefore did not find the picture interesting. Just like the other boys, he assumed that the fact that they are boys would homosexualize such an interest and thus homosexualize them as users. This homosexualized user apparently was one of the user categories initially silenced by the all-encompassing and de-personalised user categories "people" and "you", but it was a user category that the young boys were urged to articulate when confronted with pictures of male bodies. However, the pronoun "I" was used in almost all the quotations above, where the young boys emphasise their disinterest in the pictures of male bodies. These "I"s were carved out of the homosexualized user category and combined with the interest in female bodies generally associated with male users. In the first place, articulating the homosexual user category involved depriving this interest of its all-encompassing and de-personalised character - though it obviously still was the place to be and the norm. Next, carving out the "I"s of the homosexualised user category apparently made it possible for the young boys to position themselves within this norm in spite of viewing and talking about male bodies during the interviews.
Furthermore, it made it possible for them to talk about the male bodies in pornography from that position.

\section{A Supporting Body}

The young boys described the male bodies in pornography as "ugly" (Anders). Exceptionally, they could have "enormous upper arms" and be "big and strong" (Jacob). But most of the time, they are not. Rather they "have the ugliest upper bodies" and "their faces look like bulldogs" (Linus). But unsurprisingly the young boys did not express too much concern about this. According to them, the male bodies are supposed to blend into the interior anyway. And, more importantly, their ugliness makes the female bodies - the object of their interest and focus of their attention look even more spectacular: "They're not as made up. They're just there. They're not shined up like the girls", as Magnus stated. “[But] it doesn't matter - it's not important. What's important is the sexual act, or what it's called, and of course that they have made the woman gorgeous", Sune said.

à The young boys, by this, construed the male body as a supporting body - a body which is there to contribute to the sexual act, while the female body plays the leading part. Therefore, the male body is there to emphasise the female body. Even when asked directly about the male body, the young boys tended to make detours around the female body. It was through the descriptions of the looks, movements, sighs, etc. of the female body that the male body was described. In their accounts, it came to life in its relation to the female body - its primary raison d'être. The penis was no exception. But in contrast to the rest of the male body, it was the subject of some descriptions. "You don't see the man, you see his crotch and his organ", as Magnus put it. "He doesn't have to have a great upper body - the emphasis is on his organ", as 
Sune said. "He only has to deliver the equipment", as Jacob stated. But not deliver just any equipment, it could be added. "In the porn-business you have to have a long and thick cock", Linus said bluntly. "They only use men with penises that are 25 or 30 centimetres or something like that, which is quite big", Jacob said. And apparently Sune agreed: "The men have a colossal knob, you know, cock or something".

Though it was construed in relation to the female body, the boys talked remarkably fluently about the penis - the epitomization of male sexuality - which was singled out as the only male body-part of any importance. But, interestingly, by putting a delimited focus on the penis, they not only separated it from the rest of the male body. They also seemed to separate it from the sexuality of the male body. Though an epitomization of male sexuality, separated from its male body-context, the penis in other words became deprived from the sexuality that it epitomizes. Instead it became an empty organ with well-defined outer features, used to satisfy the female body, but with no distinct sexual sensibilities, desires, orientations, qualities, etc. of its own. What was left was a well-designed dildo of flesh and blood - but without the characteristics normally associated with a penis of flesh and blood. It became strictly a means by which to satisfy the sexual needs of the female body.

On the face of it, the singling out of the penis could seem like a barrier-breaking way for the young boys to talk about male bodies - a way for them to relate to the sexuality of the male body in pornography. However on a closer look it seems to add to their attempts to desexualise their viewing of male bodies: By carving out an "I" from the homosexualised user category they earlier attempted to desexualise themselves as viewers. By now separating the penis from its male body context they moreover deprived the male body on the screen of its sexuality. With these attempts to desexualise both the male user category and the viewed male body, the male-male relationship was cleansed of any potential sexuality.

\section{Passive Men, Active Women}

When the young boys reduce the male body to a penis, and reduce that penis to a dildo, they not only deprive the male characters of their sexuality. They also seem to deprive them of their subjectivity. In the young boys' descriptions of the relationships between male and female characters, the female characters seem to be the only driving forces - the ones who create the action and thus the ones who shape the theatrical dynamics. The male characters on the other hand go passively with the flow created by the female characters. As the main exhibits of pornography, the female characters may be objectified. But in the young boys' accounts this does not deprive them of their subjectivity:

"You follow the girls through a whole film, whereas there are constantly different men. And the men don't want to have sex all the time, but they get it all the time, in unexpected situations, where they catch up with people, honk at them, and then they get into the car - not very realistic. So the men aren't starved for sex like the women are - they're just there getting it" (Magnus).

The young boys' objectification of the female characters seems to go hand in hand with an equally important subjectification: Though in the power of their sexual needs, the women act to fulfil these needs. The women are displayed as "horny" (Anders) and seeking "sex all the time in all places and in all possible ways" (Magnus). And in order to get this sex, they make use of all sorts of means, which will make them end up having sex with "their boss or the mailman" (Magnus). Deprived of their own 
sexuality, the male characters do not have similar needs to fulfil, and therefore do not attempt to get anything apart form what is given to them. According to Magnus, "Men are just objects used to create the movie". And, one might add, they also are objects for the female characters, which use them to get what they want. The women might be the primary objects for the male viewers, but in the porn-movies they seem to objectify the men. Although Jacob argues that pornography is "very male-chauvinist", as "the women are just there to get fucked, if you feel like it", the other boys clearly have a different point of view: the women in porn-movies are there to get fucked, whenever they feel like it themselves. The male characters - in the form of dildos of flesh and blood - deliver the fucks. And the young boys in the form of the generalised user categories "you", "people" and even the less generalised "I" watch the women enjoying this delivery. Though pornography may be "created by men for men", as Magnus stated in the beginning, it does not mean that gender relations in pornography necessarily are represented in men's favour. On the contrary, according to most of the young boys, it seems to be the other way round: Women are in charge... not least of men.

\section{A Hypothetical Female Perspective}

Interestingly, there seems to be a user category which makes it possible for the young boys to describe male bodies as more than objectified dildos giving women what they want. This user category enables the young boys to ascribe some sexuality and subjectivity to the male bodies. And it even does so without compromising the boys' insistence on positioning themselves as heterosexual users. The price they have to pay is to give up the male user categories and position themselves as female users. Thus, in some passages during the interviews, some of the young boys take up a female perspective and go beyond the de-sexualised and de-subjectified interpretations of male characters presented above. This is mostly done in the interview passages where they are asked to comment on pictures of male bodies - and thus in passages where they deal indirectly with pornography. When asked to comment on these pictures, they could be saying: "This is not the kind of picture that you are turned on by as a girl". Or they could be saying: "That's not the first thing a girl would think of when looking at an upper-body". Or even: "Some girls are crazy about hair, but normally they (men) are shaved in pictures" (Sune). And after having taken up this female perspective they were able to elaborate on various aspects of the boys' looks, sexualities, personalities etc. (i.e., whether they had "good upper-bodies" or not (Aske, Jacob, Sune), and whether they were "horny" or not (Linus)).

But even though a female perspective is adopted mostly in passages where the young boys are asked to comment on pictures of male bodies presented to them in the interview situation, these comments sometimes spill-over into direct talk about male bodies in pornography:

"Then he [the boy in the photograph] is wearing a gold-chain. They always wear that in porn-movies, I think. You know, goldchains and a certain shirt... It shows you've got money... Everybody who has a lot of money has a lot of chicks. And... everybody with lots of money has lots of chicks - that's the way it works most of the time".

- Why is that so?

"Because girls are attracted by money and power." (Jens).

On the face of it, Jens delivers a rather conventional interpretation of gender and sexuality in this sequence. But his talk nevertheless exceeds the interpretations of the male characters in pornography otherwise 
presented in the interviews. Without fixating on the penis, he not only gives the male character a life of his own, but he also ascribes some sexual and subjective qualities to him, which are absent in the boys' talk about the male bodies in pornography from the usual user categories "you", "people" and "I". Though the female perspective is less explicit than in the boys' talk about the pictures presented during the interviews, he seems to look at the male character in pornography from an implicitly female perspective. And by doing that he apparently opens up a communicative space where the potentially homosexualised relationship between the male user and the male character is replaced by a female-male relationship, which makes it possible for him to elaborate on the male character in ways he otherwise would be unlikely to do.

The young boys have another way of establishing a female-male relationship, which opens up a similar communicative space. Instead of exchanging the male user category with a female one, they exchange the depicted male body with a female body. This is done by saying: "If that had been a girl, it could have been quite seductive". Or by saying: "If that had been a girl, I'd say no thanks" (Sune). This manoeuvre also gives them an opportunity to relate to the male bodies without having to enter the potentially homosexualised relationship between a male user category and a depicted male body. However, this particular gender-change manoeuvre only takes place in relation to the pictures presented to them during the interviews. It does not spill over to direct talk about male bodies in pornography. They are never replaced by female bodies like the male user category was replaced by a female category.

Both gender-changes - whether applied to the user category or the depicted body nevertheless show how important gender is in the viewing situation. What can be seen, and how it can be seen, depend very much on the gender associated with the seer as well as the seen. But it also shows some of the regulatory power that heterosexuality has over gender. In order to maintain their heterosexuality, the young boys position themselves contrary to their normal gender position. Momentarily, heterosexuality so to speak drives them out of their maleness and into femaleness. This not only challenges the young boys' apparently unquestioned male gender positions. It also challenges the notion that pornography per se is made for men by men. Viewing it from a female perspective means viewing something else. And perhaps this something else could be appealing to a female viewer? The interviews with the young boys cannot really provide an answer to that question. Contrary to the other positions that they assume in the interviews, the female positions to some extend appear hypothetical. They assume the user categories "you", "people" and "I" associated with maleness with a considerable conviction. However constructed and changeable these categories may be, the young boys merge into them, become them, when they use them in the interview-context. The female user categories however are kept at a noticeable distance. When talking from a female perspective, they constantly mention that they do so - as if they have to convince themselves that this can be done.

\section{Discussion}

On the face of it, the young boys' constructions of the relationship between the male viewer and the male body in pornography make up a well-known pattern. It is a pattern that to a great extent follows the notion of the male spectator and the female spectacle, in accordance with modern conceptions of gender and sexuality. These conceptions still seem to inform the young boys that it is okay to look at pornography - but only at the female characters. Doing otherwise apparently would undermine the masculinity inherent in being boys - 
though they never explicitly articulate this in the interviews. However, they do articulate that it would undermine their identities as heterosexual, and this seems to be seen as a real threat - so real, in fact, that the boys are willing to momentarily suspend the masculinity inherent in being boys and replace it with the femininity associated with assuming a female user category. By assuming this category they can direct their attention away from the female characters in pornography and glance at the male characters.

However, the female user category is somehow hypothetical. It is not really theirs - it is something they borrow from girls, to whom it really belongs. And the young boys quickly deliver it back after having used it, and then re-assume a male user category with its more limited visual angle. For a moment the femininity associated with the female user category may rub off onto the young boys, but the next moment it is replaced by the masculinity associated with a male user category. In line with other studies on gender relations among youth in late-modern Scandinavia, it seems that gender-flexibility still must relate to modern gender dichotomies (Søndergaard 1996, Johansson 2005, Sørensen $2005,2006)$. It still seems important for the young boys to construct themselves as predominantly masculine. However, in moments during the interview where heterosexuality is at stake, heterosexuality and not masculinity seems to be their priority.

Of course it can be argued that this priority does not necessarily reflect that they find heterosexuality more important than masculinity. Instead it may reflect that they find their own masculinity less challenged during the interviews: the young boys may think that their male bodies in themselves connotate masculinity and that masculinity, by this, is an inevitable part of their selfpresentation during the interviews. The same may not the case, it can be further argued, with their heterosexuality, wherefore the boys find it more urgent to articulate their heterosexuality. According to this argument, the young boys may think that their male bodies "prove" that they are masculine, wherefore the femininity of the female user category easily can be reduced to something temporary and hypothetical. However, they cannot "prove" their heterosexuality, wherefore the homosexuality associated with a young boy looking at male bodies is harder to dismiss as such. In other words, when the young boys assume a female position to emphasise their heterosexuality, they do not dismiss masculinity in favour of heterosexuality - masculinity is there no matter what.

This argument cannot merely be dismissed: the precautions with which the young boys assume the female user categories during the interviews of course indicate that they do not feel completely at home in these categories. They undoubtedly feel more comfortable with the male user categories and the masculinity associated with them. On the other hand, the mere fact that they effortlessly and competently shift to the female positions during the interviews indicate that this is not a one-off affair. It is something they seem to have done before and even something they may be used to doing. Female positions and femininity in other words are likely to be an integrated part of the ways the young boys relate to pornography. The masculinity so entwined with their male bodies is not allencompassing - it is full of cracks and holes filled with female positions and femininity. Even though the young boys may be reluctant to identify with these cracks and holes, their mere presence is likely to counter an experience of masculinity as emanating from their male bodies in a self-evident and unquestionable manner. In fact, they are likely to produce a feeling that this may not always be the case, and that masculinity, just like heterosexuality, cannot be taken for granted but sometimes must be acquired actively. 
By this, it cannot simply be assumed that the young boys give priority to heterosexuality rather than masculinity, simply because masculinity is considered an unbreakable constant. Rather it indicates that heterosexuality still is of tremendous importance as a regulatory norm, and that it has become relatively detached from modern gender dichotomies, just like bridging these dichotomies has become relatively detached from homosexuality. In particular situations - e.g. when encouraged to look at male bodies during the interviews - this situation can even be turned around. In that case, bridging gender dichotomies seems to be related to heterosexuality. However, doing that as a rule rather than as an exception might still have the opposite effect. But as long as there is an overall maintenance of gender dichotomies, there seems to be an incontestable flexibility in the relationship between gender and sexuality that can be used strategically when needed.

Scrutinizing this use in detail even suggests a further transformation of modern gender dichotomies. Thus, on a closer look, it does not merely involve an ability to shift from a male to a female user category and thereby to take up the position of the other gender. It also seems to involve a certain transformation of the characteristics associated with male and female user categories. Though at first quite unshakable in their loyalty to modern gender dichotomies - men look at pornography to look at women who are there to be looked at but not to look themselves - shifting to a female user category does not keep the young boys from looking. In fact it seems to improve their ability to look, which by no means appears incompatible with this position. Furthermore it reveals the men in pornography who are being looked at. They are transformed from dildos, deprived of any sexual or subjective qualities worth identifying with, into subjects whom the young boys may even feel some affiliation with. The obviousness with which the young boys approach the men from the female user positions even suggests that being looked at is something they are familiar with themselves. Assuming a female position not only makes the young boys articulate nuances of the men in pornography that they otherwise do not articulate, it also puts forward nuances of them-selves that are otherwise not put forward. However hypothetical it may be, assuming a female position seems to enable the young boys to reconstruct modern gender dichotomies in ways that are not merely hypothetical.

\section{Notes}

1. The presentation is further developed in "Bare billeder? - Konstruktion af køn, kroppe og seksualiteter i unge drenges brug af pornografi og mainstreamet pornografi” (Sørensen 2007).

2. My translation of the interview here and in the following.

\section{REFERENCES}

- Björk, Nina (1999). Sireners sång. Tankar kring modernitet och kön.Stockholm: Wahlström \& Widstrand.

- Bordo, Susan (2000). Mandekroppen. København: Tiderne skifter.

- Butler, Judith (1993). Bodies that matter. On the Discursive Limits of "Sex". New York: Routledge. - Connell, Robert W. (1995). Masculinities. Cambridge: Polity Press.

. Eck, Beth A. (2003): MEN ARE MUCH HARDER. Gendered Viewing of Nude Images. In: Gender \& Society 5, pp. 691-710.

. Edwards, Tim (1997). Men in the Mirror. Men's Fashions, Masculinity and Consumer Society London: Cassel.

- Gill, Rosalind, Henwood, Karen \& McLean, Carl (2003). A Genealogical Approach to idealized Male Body Imagery. In: Judith Still (Ed.), Men's Bodies, special edition of Paragraph 26, no. 1 and 2 March-July. Edinburgh: Edinburgh University Press.

. Høst, Lisbeth Vestergaard (2002). Fri os for pornotopia. In. Monica Krog Meyer (ed.) Pik, patter 
og penge - pornopficeringen af vores liv. København: Rosinante.

- Johansson, Thomas (1997). Den skulpterade kroppen. Gymkultur, friskvård och estetik.

Stockholm: Carlssons Bokförlag.

· Johansson, Thomas (red.) (2005): Manlighetens omvandlingar. Ungdom, sexualitet och kön i heteronormativitetens gränstrakter. Göteborg: Daidalos.

- Mort, Frank (1996). Cultures of Consumption. Masculinities and Social Space in Late TwentiethCentury Britain. London: Routledge

. Still, Judith (2003). (Re)presenting Masculinities: Introduction to Men's Bodies. In: Judith Still (ed.) Men's Bodies - Paragraph 26, no. 1 og 2. Edinburgh: Edinburgh University Press - Søndergaard, Dorte Marie (1996). Tegnet på kroppen. Køn: Koder og konstruktion blandt unge voksne i Akademia. København: Museum Tusculanumas Forlag

- Sørensen, Anette Dina (2003). Porn Chic - køn og mainstreaming af pornografi i massekulturen. In: Bibi Hølge-Hazelton (Ed.), Perspektiver på ungdom og krop. Roskilde: Roskilde Universitetsforlag

- Sørensen, Anette Dina \& Kjørholt, Vigdis (2007). How do Nordic adolescents relate to pornography? A quantitative study. In Susanne V.

Knudsen, Lotta Löfgren-Mårtenson and Sven-Axel Månsson (eds.) Generation P? Youth, Gender and Pornography. Copenhagen: Danish School of Education Press

- Sørensen, Niels Ulrik (2005). Meget mere end metroseksuel. Krop, køn og identitet blandt unge mænd i den senmoderne massekultur. Roskilde: Forskerskolen i Livslang Læring, Roskilde Universitetscenter.

- Sørensen, Niels Ulrik (2006). På kanten - æstetisering af det maskuline og heteroseksuelle blandt unge mænd i en senmoderne storby. In NORMA Nordic Journal of Masculinity Studies No 1, pp. 122-149

- Sørensen, Niels Ulrik (2007). Bare billeder? Konstruktion af køn, kroppe og seksualiteter i unge drenges brug af pornografi og mainstreamet pornografi. In: Anette Dina Sørensen \& Susanne V. Knudsen (Ed.) Unge, køn og pornografi i Norden - Kvalitative studier. TemaNord:545. København: Norden.

\section{SUMMARY}

This article analyses young boys' descriptions of their meetings with male bodies in pornography. It is based on qualitative interviews with 15 and 16 year old boys performed in the NIKK-project "Youth, gender and pornography in the Nordic countries", which took place in 2005 and 2006. The article explores the tension between the masculine and the feminine, the homosexual and the heterosexual generated during these meetings. Especially it focuses on the tension related to the young boys' attempts to assume masculine and heterosexual positions and the feminisation and homosexualisation inherent in their looking at male bodies in pornography. The article shows that the boys pursue various strategies to reinterpret body, gender and sexuality in order to avoid this feminisation and homosexualisation. However this reinterpretation sometimes creates friction between the masculine and the heterosexual, and the boys feel that they cannot position themselves as both - they have to choose between masculinity or heterosexuality. The article explores how and what they choose.

Niels Ulrik Sørensen er lektor, ph.d. ved Center for Ungdomsforskning, Learning Lab Danmark, Danmarks Pædagogiske Universitetsskole, Aarhus Universitet

Denne artikel er en forkortet udgave af artiklen Detours for Heterosexuality - Young boys viewing male bodies in pornography, der indgår i antologien Generation P? Youth, Gender and Pornography. Antologien, der er redigeret af Susanne V. Knudsen, Lotta Löfgren-Mårtenson og Sven-Axel Månsson, udkom på Danmarks Pædagogiske Universitetsforlag 2007. 